\title{
KOLAM TAMPUNGAN SEBAGAI BANGUNAN PENGENDALI GENANGAN DI KECAMATAN SAMPANG
}

\author{
Mizun Bariroh Anis ${ }^{1}$, Soehardjono ${ }^{2}$, Ussy Andawayanti². \\ ${ }^{1}$ Staf Dinas Pekerjaan Umum dan Penataan Ruang Kabupaten Sampang, \\ ${ }^{2}$ Pengajar Program magister Teknik Pengairan Universitas Brawijaya, Malang, Jawa Timur, \\ mizun_ba@yahoo.com
}

\begin{abstract}
ABSTRAK : Kecamatan Sampang seringkali dilanda banjir sehingga menggenangi wilayah permukiman dan persawahan yang ada. Tujuan kajian ini yaitu menganalisa kapasitas tampungan saluran drainase dan kolam tampungan eksisiting, pengaruh pasang surut air laut dan upaya penanggulangannya. Hasil kajian ini diperoleh 8 saluran kala ulang 5 tahun dan 13 saluran kala ulang 10 tahun yang tidak mampu menampung debit banjir rencana sehingga dilakukan perubahan dimensi dengan meningkatkan kapasitas saluran. Pengaruh pasang surut air laut terhadap genangan dari sungai Kamoning dari hilir menuju hulu sejauh $537 \mathrm{~m}$ adalah $0.6 \mathrm{~m}$. Upaya penanggulangan genangan ada 6 buah kolam tampungan yang direncanakan yaitu di desa Pliyang dengan volume tampungan efektifnya sebesar $52.966 \mathrm{~m}^{3}$, di Jl. Manggis A dengan volume tampungan efektifnya sebesar $6.402 \mathrm{~m}^{3}$, di Jl. Manggis B dengan volume tampungan efektifnya sebesar $6.168 \mathrm{~m}^{3}$, di Jl. Manggis C dengan volume tampungan efektifnya sebesar $8.370 \mathrm{~m}^{3}$, di desa Paseyan dengan volume tampungan efektifnya sebesar $17.188 \mathrm{~m}^{3}$, dan di Jl. Imam Bonjol dengan volume tampungan efektifnya sebesar $56.594 \mathrm{~m}^{3}$. Hasil analisis efektifitas bahwa kolam tampungan mampu mereduksi sebesar $100 \%$.
\end{abstract}

Kata-kata kunci: drainase, back water, kolam tampugan, debit banjir, curah hujan

\begin{abstract}
Subdistrict Sampang often hit by floods that inundated residential areas and paddy fields there. The purpose of this study is to analyze the storage capacity of the drainage channels and ponds eksisiting, the influence of the tide and preventive efforts. The study results were obtained when the 8 channels and 13 channels 5-year return period of 10 years who are not able to accommodate the flood discharge plan so that a dimensional change by changing the height and width dimensions. The influence of the tide against the inundation of the river Kamoning on peg 28 on the downstream toward the upstream channel B12 as far as $537 \mathrm{~m}$ is $0.6 \mathrm{~m}$. Prevention efforts have 6 pieces planned pond is in the village Pliyang with the storage effective volume of $52.966 \mathrm{~m}^{3}$, at Manggis street pond with the effective volume of $6.402 \mathrm{~m}^{3}$, at Manggis street B with the storage effective volume of $6.168 \mathrm{~m}^{3}$, at Manggis street $C$ with effective volume of $8.370 \mathrm{~m}^{3}$ effective pond, in the village Paseyan with the storage volume amounting to $17.188 \mathrm{~m}^{3}$ effective, and on Imam Bonjol street with the storage volume amounting to $56.594 \mathrm{~m}^{3}$ effective. The volume of the resulting flood of inflow into the storage pool with a return period of 5 years and 10 years for rain four hours on each pond can reduce of $100 \%$.
\end{abstract}

Key words: drainage, back water, Ponds, discharge, rainfall

Kecamatan Sampang merupakan ibukota Kabupaten Sampang yang padat penduduk sehingga menimbulkan berbagai macam permasalahan salah satunya adalah banjir. Genangan yang terjadi pada wilayah kecamatan Sampang disebabkan oleh beberapa persoalan yaitu kurang berfungsinya saluran drainase, adanya luapan dari sungai akibat debit yang mengalir di sungai melebihi kapasitas sungai, dan terjadinya arus balik (back water). Arus balik biasanya terjadi pada wilayah perkotaan yang terletak di hilir sungai atau daerah pantai sehingga dipengaruhi oleh pasang surut air laut yang mengakibatkan 
sungai dapat meluap. Selain itu genangan juga diakibatkan oleh permasalahan sosial seperti banyaknya sampah yang masuk kedalam saluran drainase karena ketidak pedulian masyarakat terhadap lingkungan.

Secara umum permasalahan yang ingin dikaji dalam penelitian ini yaitu morfologi sungai Kemuning bagian hilir yang masuk wilayah Kota Sampang yang berkelok-kelok dan adanya penurunan daya tampung palung sungai yang disebabkan oleh erosi pada daerah hulu hingga hilir DAS mengakibatkan sedimentasi pada dasar sungai dan penyempitan pada kanan-kiri badan sungai terutama pada muara sungai sehingga menghambat proses pengaliran air dari badan sungai menuju muara sungai Kamoning. Pada saat permukaan air sungai naik akibat pasang, terjadi aliran balik ke sungai kemudian masuk ke dalam saluran drainase yang mengakibatkan permukaan air lebih tinggi dari sebagian lahan sehingga timbul genangan, perubahan tata guna lahan di Kecamatan Sampang juga mempengaruhi sistem aliran yang berhubungan dengan sistem drainase kota. Salah satu faktor yang memicu terjadinya genangan adalah berubahnya lahan pertanian menjadi lahan permukiman, sehingga berkurangnya media peresapan air dan mengakibatkan limpasan permukaan (run off) semakin besar (Cahyono, 2013).

Tujuan yang ingin dicapai dalam penelitian ini adalah Mendapatkan alternatif solusi pengendalian genangan yang ada pada daerah penelitian dengan cara menganalisa kapasitas tampungan saluran drainase dan kolam tampungan eksisiting dan menganalisa pengaruh pasang surut air laut terhadap genangan.

\section{Hujan Rancangan}

Curah hujan yang diperlukan untuk penyusunan suatu rancangan pemanfaatan air dan rancangan pengendalian banjir adalah curah hujan rata-rata di seluruh daerah yang bersangkutan dinyatakan dalam satuan milimeter (Sosrodarsono, 2003). Curah hujan rancangan adalah curah hujan terbesar tahunan dengan suatu probabilitas kejadian tertentu dalam periode ulang tertentu.

Curah hujan rancangan dihitung berdasarkan analisis probabilitas frekuensi dengan mengacu pada SK SNI M-18-1989 tentang Metode Perhitungan debit banjir. Analisa frekuensi yang dilakukan untuk memperkirakan/meramalkan curah hujan maksimum dapat menggunakan metode distribusi Nomal, Log Pearson Type III, dan Gumbel. Pemilihan dari tiga metode ini menggunakan uji kesesuaian distribusi yaitu uji smirnov Kolmogorov dan uji Chi Square dengan melihat nilai simpangan yang terkecil.

\section{Debit Banjir Rencana}

Debit banjir rencana untuk drainase perkotaan, umumnya dihitung dengan rumus rasional, karena daerah aliran yang tidak terlalu luas, waktu monsentrasi yang relatif pendek dam kehilangan air sedikit. Rumus umum metode rasional adalah (Suhardjono, 2015) :

$$
\mathrm{Q}=0,278 \text {. C . I . A }
$$

dengan :

$\mathrm{Q}=$ debit limpasan $\left(\mathrm{m}^{3} / \mathrm{dtk}\right)$

$\mathrm{C} \quad=$ koefisien pengaliran

I =Intensitas hujan selama waktu tiba banjir ( $\mathrm{mm} / \mathrm{jam})$

A $=$ Luas daerah pengaliran $\left(\mathrm{km}^{2}\right)$

$0,278=$ faktor konversi

\section{Koefisien Pengaliran}

Koefisien Pengaliran adalah perbandingan antara jumlah air yang mengalir di permukaan akibat hujan (limpasan) dengan jumlah curah hujan yang turun di daerah tersebut. Hal ini karena air hujan tidak semuanya melimpas, selalu ada yang tertahan dalam kawasan, masuk dalam tanah, menguap dan laian-lain. Besarnya koefisien limpasan (C) untuk rancangan drainase perkotaan adalah (Suhardjono, 2015):

$$
C=\sum_{i=1}^{n} \frac{A_{i} C_{i}}{A_{i}}
$$

\section{Intensitas Hujan}

Intensitas hujan adalah jumlah curah hujan yang dinyatakan dalam tinggi hujan (mm/jam) tiap satuan waktu, yang terjadi pada satu durasi waktu, di saat air hujan terkonsentrasi. Rumus yang dipakai dalam perhitungan intensitas hujan di kawasan perkotaan adalah rumus mononobe (Suhardjono, 2015) :

$$
I=\frac{R_{24}}{24}\left(\frac{24}{t c}\right)^{2 / 3}
$$


dengan:

I = Intensitas hujan selama waktu konsentrasi ( $\mathrm{mm} / \mathrm{jam})$

R24 = tinggi curah hujan maksimum harian dalam 24 jam (mm)

tc $\quad=$ Waktu konsentrasi (jam)

\section{Waktu konsentrasi}

Waktu konsentrasi atau waktu tiba banjir adalah waktu yang diperlukan oleh air hujan untuk mengalir dari suatu titik yang paling jauh ke suatu titik tinjau tertentu (misalnya titik di muara drainase) pada suatu daerah pengaliran (Suripin, 2004) :

$$
\text { tc }=\text { to }+ \text { td }
$$

dengan:

to = waktu limpasan permukaan (menit).

td =lama pengaliran dalam saluran (menit)

tc = waktu konsentrasi (menit)

\section{Debit saluran}

Analisa kapasitas saluran dilakukan untuk mengetahui kemampuan saluran yang ada terhadap debit rencana hasil perhitungan. Apabila kapasitas saluran lebih besar dari debit rencana maka saluran tersebut masih mampu dan tidak ada luapan air/genangan. Perencanaan dimensi penampang saluran menggunakan aliran seragam. Penentuan dimensi saluran ini menggunakan rumus Manning, karena mempunyai bentuk yang sederhanan tetapi memeberikan hasil yang memuaskan (Chow, 1989).

$$
\begin{aligned}
& \mathrm{V}=1 / \mathrm{n} \cdot \mathrm{R}^{2 / 3} \cdot \mathrm{S}^{1 / 2} \\
& \mathrm{Q}=\mathrm{A} \cdot \mathrm{V}=\mathrm{A} \cdot 1 / \mathrm{n} \cdot \mathrm{R}
\end{aligned}
$$

dengan:

$\mathrm{Q}=$ debit saluran $\left(\mathrm{m}^{3} / \mathrm{det}\right)$

$\mathrm{V}=$ kecepatan aliran $(\mathrm{m} / \mathrm{det})$

$\mathrm{A}=$ luas penampang basah $(\mathrm{m}$

$\mathrm{n}=$ angka kekasaran saluran (m)

$\mathrm{R}=$ jari-jari hidrolis saluran $(\mathrm{m})$

$\mathrm{S}=$ kemiringan dasar saluran.

Evaluasi saluran adalah untuk mengetahui seberapa besar debit yang dapat ditampung saluran dengan kondisi yang ada saat ini.

\section{Pasang surut air laut}

Pasang surut adalah gerakan naikturunnya air laut, dimana amplitudo dan fasenya berhubungan langsung terhadap gaya geofisika yang periodic, yaitu gaya yang ditimbulkan oleh gerak regular benda-benda angkasa terutama bumi, bulan dan matahari (Suripin, 2004).
Dalam oseanografi, pasang surut dikelompokkan dalam empat tipe, yaitu: (a) Pasang surut harian ganda (semi diurnal tide) (b) Pasang surut harian tunggal (diurnal tide) (c) Pasang surut campuran condong ke harian ganda (mixed tide prevailing semidiurnal). (d) Pasang surut campuran condong ke harian tunggal (mixed tide prevailing diurnal).

\section{Analisa Profil Aliran}

Elevasi muka air pada alur sungai perlu dianalisis untuk mengetahui pada sisi mana terjadi luapan pada alur sungai. Sebagai alat bantu analisa profil muka air digunakan program HEC-RAS 5.1. Prosedur perhitungan didasarkan pada penyelesaian persamaan aliran satu dimensi melalui saluran terbuka. Aliran satu dimensi ditandai dengan besarnya kecepatan yang sama pada seluruh penampang atau digunakan kecepatan rata-rata.

\section{Analisa Back Water}

Analisa Back water atau profil air balik diperlukan untuk mengetahui ketinggian air pada jarak tertentu akibat bertemunya saluran pembuang akhir dengan muaranya. Elevasi air yang terjadi dapat dianalisis dengan metode tahapan langsung (direct step method). Seperti yang ditunjukkan pada Gambar 1, analisi profil air balik diperlukan untuk menentukan sampai seberapa jauh pengaruh kenaikan muka air di saluran akibat pasang surut air laut. Perhitungan profil muka air dimulai dengan kedalaman yang diketahui $\mathrm{h}_{1}$, yang diperoleh dari hubungan kedalama debit (Rating curve). Kedalaman $\mathrm{h}_{2}$, baik di hulu atau dihilirnya tergantung pada jenis aliran subkritis atau superkritis, dan dihitung DX antara kedua kedalaman tersebut.

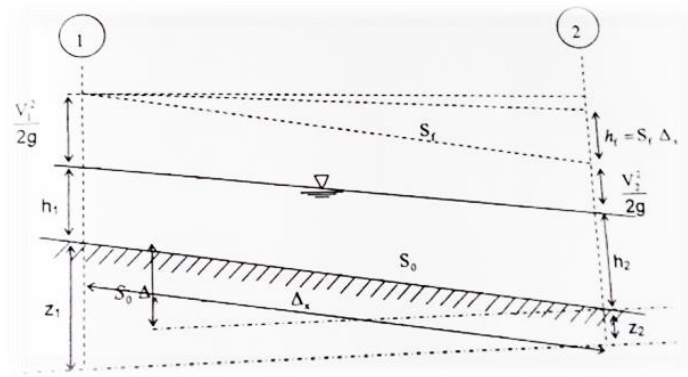

Gambar 1 profil muka air metode tahapan langsung sumber : (Suripin, 2004)

\section{Penanganan Pengendalian Genangan} Penangangan pengendalian genangan dalam studi ini adalah perbaikan saluran dan 
kolam Tampungan. Kolam tampungan adalah salah satu cara pengendailian debit puncak yaitu dengan menurunkan puncak banjir sehingga terjadi banjir yang tiba-tiba dengan waktu yang singkat, cara ini cocok untuk mengendalikan banjir jhususnya di kota pesisir.

\section{BAHAN DAN METODE}

Secara Astronomis Kabupaten Sampang terletak berada pada $113^{\circ} 08^{\prime}-113^{\circ} 39^{\prime}$ Bujur Timur dan $06^{\circ} 05^{\prime}-07^{\circ} 13^{\prime}$. luas Kecamatan Sampang sebesar 70,01 $\mathrm{km}^{2}$ atau $5,68 \%$ dari seluruh kabupaten Sampang (BPS Sampang, 2015). Berdasarkan data dari Dinas PU Pengairan kabupaten Sampang maka genangan yang terjadi di wilayah kecamatan Sampang dapat ditunjukkan pada Gambar 2.

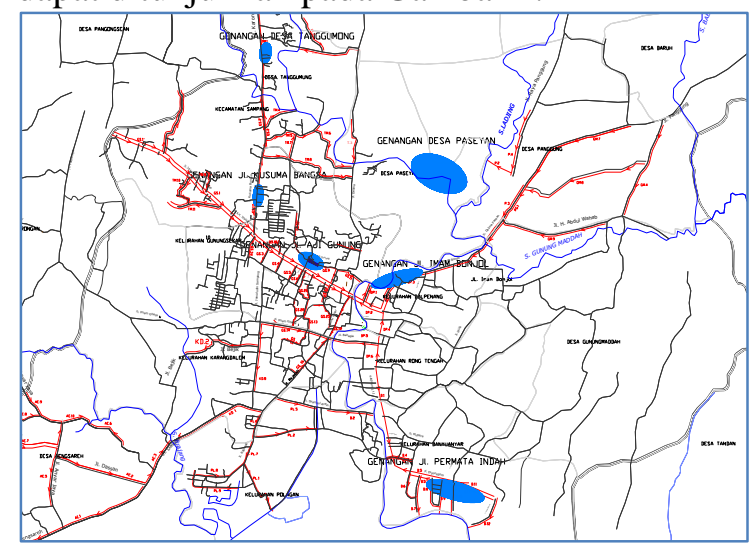

Gambar 2. Peta Genangan di Kecamatan Sampang

Analisis yang dilakukan pada penelitian ini terdiri dari :

a. Menghitung curah hujan maksimum daerah dengan menggunakan cara rata-rata aljabar

b. Melakukan uji konsistensi data dengan metode lengkung massa ganda

c. Menghitung curah hujan rancangan dengan metode distribusi normal, Log Pearson tipe III dan gumbel, kemudian dilakukan uji frekuensi dengan uji Smirnov kolmogorov dan uji Chi-kuadrat yang bertujuan untuk mengetahui kebenaran hipotesa distribusi frekuensi log pearson tipe III.

d. Menghitung Intensitas hujan dengan menggunakan rumus manonobe.

e. Menentukan koefisien pengaliran dengan menghitung besarnya luasan penggunaan lahan pada setiap saluran yang dikaji berdasarkan peta tata guna lahan.

f. Menghitung Laju aliran puncak (debit banjir) dengan menggunakan metode rasional. g. Menghitung kapasitas saluran drainase eksisiting berdasarkan data dimensi saluran yang ada.

h. Menghitung selisih debit antara kapasitas saluran dengan debit rancangan untuk mengetahui saluran yang tidak mampu menampung debit rancangan.

i. Menghitung pengaruh pasang surut air laut terhadap genangan berdasarkan data pasang surut air laut dan data profil memanjang dan lintang sungai.

j. Menghitung kapasitas tampungan berdasarkan lahan yang tersedia

Menganalisa efektivitas kolam tampungan yang direncanakan.

\section{HASIL DAN PEMBAHASAN}

\section{Uji Konsistensi Data}

Pengujian data hujan perlu dilakukan sebelum melakukan analisa hidrologi. Studi ini menggunakan metode uji konsistensi dengan kurva massa ganda.

Hasil perhitungan uji konsistensi pada stasiun kedungdung, Sampang dan Omben menunjukkan bahwa data hujan mempunyai nilai $\mathrm{R}$ mendekati 1 berarti data hujan konsisten sehingga digunakan sebagai dasar analisa.

\section{Uji Abnormalitas Data}

Uji ini digunakan untuk mengetahui apakah data maksimum dan minimum dari rangkaian data yang ada layak digunakan atau tidak. Uji yang digunakan adalah uji InlierOutlier.

Tabel 1. Uji Abnormalitas data dengan Inlier-0utlier curah hujan maksimum

\begin{tabular}{|c|c|c|c|c|c|c|c|}
\hline \multirow{2}{*}{ No. } & \multicolumn{2}{|c|}{ Data yang sudah diranking } & \multirow{2}{*}{$\log X$} & \multirow{2}{*}{ No. } & \multicolumn{2}{|c|}{ Data yang sudah diranking } & \multirow{2}{*}{$\log X$} \\
\hline & Tahun & $\mathrm{Rn}(\mathrm{mm})$ & & & Tahun & $\mathrm{Rn}(\mathrm{mm})$ & \\
\hline 1 & 2002 & 121.67 & 2.0852 & 13 & 2003 & 35.00 & 1.5441 \\
\hline 2 & 2006 & 89.67 & 1.9526 & 14 & 2014 & 35.00 & 1.5441 \\
\hline 3 & 2015 & 60.33 & 1.7806 & 15 & 1992 & 34.67 & 1.5399 \\
\hline 4 & 2007 & 48.00 & 1.6812 & 16 & 1993 & 34.33 & 1.5357 \\
\hline 5 & 1996 & 47.33 & 1.6752 & 17 & 2013 & 32.67 & 1.5141 \\
\hline 6 & 1998 & 45.00 & 1.6532 & 18 & 2005 & 32.33 & 1.5097 \\
\hline 7 & 1999 & 44.67 & 1.6500 & 19 & 2010 & 31.33 & 1.4960 \\
\hline 8 & 2009 & 42.67 & 1.6301 & 20 & 2008 & 31.00 & 1.4914 \\
\hline 9 & 2000 & 41.00 & 1.6128 & 21 & 2011 & 30.67 & 1.4867 \\
\hline 10 & 1995 & 37.67 & 1.5760 & 22 & 2001 & 30.33 & 1.4819 \\
\hline 11 & 2012 & 36.00 & 1.5563 & 23 & 1997 & 30.00 & 1.4771 \\
\hline 12 & 2004 & 35.33 & 1.5482 & 24 & 1994 & 29.33 & 1.4674 \\
\hline Stdev & \multicolumn{2}{|r|}{0.1514} & \multicolumn{3}{|c|}{ Nilai Batas Atas, Xh } & $=$ & 94.9107 \\
\hline \multicolumn{2}{|c|}{ Rerata $\log X$} & 1.6037 & & \multicolumn{3}{|c|}{ Nilai Batas bawah, $\mathrm{Xi}=$} & 16.9872 \\
\hline $\mathrm{Kn}$ & 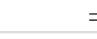 & 2.4670 & & & & & \\
\hline \multicolumn{3}{|c|}{ Data yang tidak bisa dipakai } & \multicolumn{2}{|c|}{ Tahun 2002} & & & \\
\hline
\end{tabular}

Berdasarkan tabel 1 diatas didapatkan data yang menyimpang dari batas ambang bawah (XL) dan batas ambang atas (XH) adata 
data pada tahun 2002 sehinngga tidak dipakai dalam perhitungan.

\section{Uji Kesesuaian Distribusi}

Uji kesesuaian distribusi dilakukan untuk memilih analisis frekuensi. Studi ini menggunakan metode Smirnov-Kolmogorov dan Chi-Square.

Berdasarkan uji smirnov kolmogorov menunjukkan data yang diterima dan mempunyai simpangan terkecil adalah metode Distribusi Log Pearson III. Berdasarkan Uji Chi Square, maka data yang mempunyai simpangan terkecil adalah metode Distribusi Log Pearson III seperti ditunjukkan pada Tabel 2 dan Tabel 3.

Tabel.2 Uji Smirnov Kolmogorov

\begin{tabular}{|c|c|c|c|c|c|}
\hline \multirow{2}{*}{$\begin{array}{c}\text { Kala Ulang } \\
\text { (tahun) }\end{array}$} & \multirow{2}{*}{$\mathrm{P}$} & \multirow{2}{*}{$\mathrm{t}$} & \multicolumn{2}{|c|}{ Distribusi Probability } & \multirow{2}{*}{$\begin{array}{l}\text { Distribusi yang Dipilih } \\
\text { (Log Pearson III) }\end{array}$} \\
\hline & & & Normal & Log pearson III & \\
\hline 2 & 50 & 0.00 & 39.754 & 35.489 & 35.489 \\
\hline 5 & 20 & 0.84 & 50.914 & 45.359 & 45.359 \\
\hline 10 & 10 & 1.28 & 56.747 & 54.143 & 54.143 \\
\hline 20 & 5 & 1.64 & 61.565 & 65.708 & 65.708 \\
\hline 25 & 4 & 1.75 & 62.968 & 68.302 & 68.302 \\
\hline \multicolumn{3}{|c|}{ Delta maksimum } & 0.195 & 0.066 & \\
\hline \multicolumn{3}{|c|}{ Delta Kritis (5\%) } & 0.280 & 0.280 & \\
\hline \multicolumn{6}{|c|}{ Sumber: Hasil Perhitungan } \\
\hline \multicolumn{6}{|c|}{ Tabel. 3 Uji Chi Square } \\
\hline$\alpha$ & \multicolumn{2}{|c|}{ Dkritis } & Normal & $\begin{array}{c}\text { Log } \\
\text { Pearson } \\
\text { III }\end{array}$ & $\begin{array}{c}\text { Distribusi } \\
\text { Yang Dipilih }\end{array}$ \\
\hline $1 \%$ & \multicolumn{2}{|c|}{41.638} & 22.159 & 1.743 & \multirow{2}{*}{$\begin{array}{c}\text { Distribusi } \\
\text { Log Pearson } \\
\text { III } \\
\end{array}$} \\
\hline $5 \%$ & \multicolumn{2}{|c|}{36.172} & 22.159 & 1.743 & \\
\hline
\end{tabular}

\section{Intensitas Hujan}

Perhitungan analisa intensitas hujan rencana di hitung dengan menggunakan rumus Manonobe, adapun salah satu perhitungannya pada saluran desa Banyumas (P1) :

$\begin{array}{ll}\text { Panjang saluran } & =398 \mathrm{~m} \\ \text { Kemiringan saluran } & =0,0012 \\ \text { R Maks Kala Ulang 5 Thn } & =45,359 \mathrm{~mm} \\ \text { Curah Hujan netto } & =22,466 \mathrm{~mm} \\ \text { Waktu } & =1 \text { jam } \\ \text { Intensitas Hujan 5 th } & =\frac{22,466}{6}\left(\frac{6}{1}\right)^{2 / 3} \\ & =12,363 \mathrm{~mm} / \mathrm{jam} \\ \text { Curah Hujan netto } & =26,816 \mathrm{~mm} \\ \text { Intensitas Hujan 10 thn } & =\frac{26,816}{6}\left(\frac{6}{1}\right)^{2 / 3} \\ & =14,758 \mathrm{~mm} / \mathrm{jam}\end{array}$

\section{Debit Banjir Rencana}

Dari hasil analisa terhadap data yang diperoleh besar debit rencana untuk masingmasing saluran dapat dicari dengan menggunakan metode rasional :

Contoh perhitungannya adalah :

$$
\text { Luas DTA } \quad=0,094 \mathrm{~km}^{2}
$$

$$
\begin{array}{ll}
\text { Koefisien Limpasan } & =0,437 \\
\text { Intensitas Hujan }(5 \mathrm{Thn}) & =12,363 \mathrm{~mm} / \mathrm{jam} \\
\text { Debit banjir rencana } & =0,278 \times \mathrm{CxIxA} \\
& =0,142 \mathrm{~m}^{3} / \mathrm{dtk} \\
\text { Intensitas hujan }(10 \mathrm{Thn}) & =14,758 \mathrm{~mm} / \mathrm{jam} \\
\text { Debit banjir rencana } & =0.278 \times \mathrm{C} \times \mathrm{I} \times \mathrm{A} \\
& =0,169 \mathrm{~m}^{3} / \mathrm{dtk}
\end{array}
$$

\section{Evaluasi Jaringan Drainase}

Analisa ini dilakukan sebagai kontrol terhadap perhitungan debit banjir rencana. Dari data-data yang ada dapat dihitung kapasitas maksimal debit drainase Kecamatan Sampang dengan menggunakan rumus manning.

Contoh perhitungannya adalah :

$$
\begin{array}{ll}
\text { Kemiringan Saluran } & =0,0012 \\
\text { Luas dimensi saluran (A) } & =0,560 \mathrm{~m} \\
\text { Keliling basah saluran (P) } & =2,200 \mathrm{~m} \\
\text { Jari-jari Hidrolis (R) } & =0,255 \\
\text { Koefisien Kekasaran } & =0,013 \text { (beton) } \\
\text { Kecepatan aliran (V) } & =1,070 \mathrm{~m} / \mathrm{dtk} \\
\text { Debit yang ada di saluran } & =\mathrm{V} \mathrm{x} \mathrm{A} \\
& =0,599 \mathrm{~m}^{3} / \mathrm{dtk}
\end{array}
$$

Koefisien Pengaliran $(\mathrm{C})=0,437$

Intensitas Hujan (5 tahun) $=12,363 \mathrm{~mm} / \mathrm{jam}$

$$
\begin{array}{ll}
\text { Luas DTA } & =0,0094 \mathrm{~km}^{2} \\
\text { Debit Banjir Rencana } & =0.278 \times \mathrm{C} \times \mathrm{I} \times \mathrm{A} \\
& =0,142 \mathrm{~m}^{3} / \mathrm{dtk}
\end{array}
$$

Dari perhitungan diatas dapat dilihat bahwa debit saluran sebesar $0,599 \mathrm{~m}^{3} / \mathrm{dtk}>$ debit banjir rencana sebesar $0,142 \mathrm{~m}^{3} / \mathrm{dtk}$ sehingga saluran desa Banyumas memenuhi daya tampung salurannya.

Berdasarkan hasil perbandingan kapasitas eksisting dan debit banjir rencana yang ada ada beberapa saluran yang tidak mencukupi sehingga mnyebabkan air hujan meluap dan menggenangi daerah sekitar. Dari 90 titik lokasi saluran eksisting yang ada di Kecamatan Sampang, ada 8 titik lokasi saluran draianse yang tidak mampu menampung debit rencana yang terjadi dengan kala ulang 5 tahun dan 13 titik lokasi saluran draianse yang tidak mampu menampung debit rencana yang terjadi dengan kala ulang 10 tahun.

\section{Kolam Tampungan Eksisting}

Lokasi kolam tampungan eksisiting yang ada di kecamatan Sampang terletak di tengah kota yaitu tepatnya di jalan Aji Gunung I yang merupakan tempat pengumpul dari drainase di saluran GS 18" dari jalan Durian dan Manggis. Dimensi kolam tampungan di Jl. Aji Gunung 1 adalah $95 \times 35 \times 3$ m dengan tinggi sedimen sebesar $2 \mathrm{~m}$. Berdasarkan 
evaluasi kolam tampungan didapatkan waktu pengisian kolam tampungan selama \pm 3 jam. Adapun evaluasi kolam tampungan di Jl. Aji Gunung 1 sebagai berikut:

Debit inflow dari Jalan Durian dan Manggis = $0,323 \mathrm{~m}^{3} / \mathrm{dtk}$

$$
\begin{aligned}
\text { Volume kolam } & =3.325 \mathrm{~m}^{3} \\
\text { Waktu pengisian } & =\text { Volume } / \mathrm{Q} \text { inflow } \\
& =10.282,73 \text { detik } \\
& =2.86 \mathrm{jam} \approx 3 \mathrm{jam}
\end{aligned}
$$

\section{Analisa Profil Aliran}

Analisa profil aliran ini menggunakan bantuan software HEC-RAS 5.1. Pada program HECRAS ini input yang harus dimasukkan adalah kondisi batas hulu dan hilir sungai Kamoning untuk running analisa profil muka air. Kondisi batas hulu sungai Kamoning dalam kajian ini menggunakan data debit puncak banjir rancangan metode Nakayasu yang ditunjukkan pada Tabel 4. Sedangkan Kondisi hilir sungai menggunakan elevasi banjir sebesar 3,28 $\mathrm{m}$ yang tercatat pada data AWLR.

Tabel. 4 Debit Banjir Rancangan dengen metode Nakayasu

\begin{tabular}{c|c|c|c|c|c|c}
\hline \multicolumn{7}{c}{ Debit Banjir Rancangan Kala Ulang } \\
\hline $\operatorname{Tr}$ & 2 & 5 & 10 & 20 & 25 & 50 \\
\hline $\mathrm{Q}$ & 102,452 & 128,888 & 152,417 & 183,395 & 190,343 & 224,678 \\
\hline
\end{tabular}

Berdasarkan hasil analisis HEC-RAS, debit banjir dengan kala ulang Q10 tahun sungai Kamoning mengalami bahwa terjadi banjir di semua patok.

Hasil analisis diharapkan bisa representatif terhadap kejadian sebenarnya di sungai Kamoning, maka untuk mengetahui apakah hasil running mendekati kejadian banjir yang pernah terjadi perlu dilakukan survei lapangan untuk mengukur elevasi banjir yang terjadi. Hasil survei kemudian dibandingkan dengan hasil analisis profil muka air, jika tidak ada perbedaan tinggi muka air banjir yang signifikan maka analisis dianggap bisa mewakili kondisi di sungai Kamoning.

Survei dan informasi banjir di sungai Kamoning dilakukan di jalan Permata Indah. Tinggi genangan di jalan Permata Indah tercatat $0.30 \mathrm{~m}$, kemudian di plotkan di peta kontur di dapatkan elevasi lahan pada saluran adalah $+3,00 \mathrm{~m}$. Jika di bandingkan dengan hasil analisis profil muka air, elevasi banjir pada patok 28, elevasi banjir $+3.31 \mathrm{~m}$. Berdasarkan hasil tinjauan di lapangan, didapatkan tidak ada perbedaan yang cukup signifikan antara elevasi banjir hasil analisis dan hasil survei banjir. Dengan tidak adanya perbedaan elevasi banjir yang signifikan antara hasil analisis profil muka air dengan tinjauan di lapangan, bisa dikatakan hasil analisis cukup mewakili kejadian banjir yang pernah terjadi di Sungai Kamoning.

\section{Analisa Back Water}

Untuk mengetahui analisa back water pada saluran drainase perlu dilakukan perhitungan profil muka air pada patok 28 sungai Kamoning dari hilir sungai kamoning ke hulu saluran drainase sejauh $537 \mathrm{~m}$. Untuk menghitung profil muka air tersebut metode tahapan langsung.

Dengan menggunakan rumus manning dan metode coba-coba didapatkan tinggi normal adalah $0,556 \mathrm{~m}$. Pada perhitungan profil muka air, dimulai dari kedalaman yang sudah diketahui di hilir titik kontrol, $\mathrm{h}=1,310 \mathrm{~m}$ bergerak ke arah hulu. Pada titik kontrol ini di beri notasi $\mathrm{x}=0$. Perhitungan profil muka air ini dihentikan jika kedalaman air pada kisaran

\begin{tabular}{|c|c|c|c|c|c|c|c|c|c|c|c|c|c|}
\hline $\mathrm{h}$ & A & $P$ & $R$ & $\mathrm{R}^{\wedge} 4 / 3$ & $\mathrm{~V}$ & $\mathrm{v} \wedge 2 / 2 \mathrm{~g}$ & $\mathrm{E}$ & $\mathrm{dE}$ & Sf $\mathrm{S}$ & Sf rata2 & $\mathrm{S}-\mathrm{Sf}$ & $\mathrm{dX}$ & $X$ \\
\hline $\mathrm{m}$ & $\mathrm{m} 2$ & $\mathrm{~m}$ & $\mathrm{~m}$ & & $\mathrm{~m} / \mathrm{dtk}$ & $\mathrm{m}$ & $\mathrm{m}$ & $\mathrm{m}$ & & & & $\mathrm{m}$ & $\mathrm{m}$ \\
\hline 1.31 & 0.79 & 3.22 & 0.24 & 0.15 & 1.10 & 0.06 & 1.37 & & 0.01 & & 0.00 & & 0.00 \\
\hline 1.20 & 0.72 & 3.00 & 0.24 & 0.15 & 1.20 & 0.07 & 1.27 & 0.10 & 0.01 & 0.01 & 0.00 & 87.47 & 87.47 \\
\hline 1.10 & 0.66 & 2.80 & 0.24 & 0.15 & 1.31 & 0.09 & 1.19 & 0.09 & 0.01 & 0.01 & 0.00 & 84.32 & 171.79 \\
\hline 1.00 & 0.60 & 2.60 & 0.23 & 0.14 & 1.44 & 0.11 & 1.11 & 0.08 & 0.01 & 0.01 & 0.00 & 89.12 & 260.92 \\
\hline 0.90 & 0.54 & 2.40 & 0.23 & 0.14 & 1.60 & 0.13 & 1.03 & 0.08 & 0.01 & 0.01 & 0.00 & 92.88 & 353.79 \\
\hline 0.80 & 0.48 & 2.20 & 0.22 & 0.13 & 1.80 & 0.16 & 0.96 & 0.07 & 0.01 & 0.01 & 0.00 & 86.49 & 440.29 \\
\hline 0.70 & 0.42 & 2.00 & 0.21 & 0.12 & 2.05 & 0.22 & 0.92 & 0.05 & 0.01 & 0.01 & 0.00 & 65.54 & 505.83 \\
\hline 0.60 & 0.36 & 1.80 & 0.20 & 0.12 & 2.40 & 0.29 & 0.89 & 0.02 & 0.01 & 0.01 & 0.00 & 31.79 & 537.62 \\
\hline 0.50 & 0.30 & 1.60 & 0.19 & 0.11 & 2.88 & 0.42 & 0.92 & 0.03 & 0.00 & 0.01 & 0.01 & 3.15 & 540.77 \\
\hline 0.40 & 0.24 & 1.40 & 0.17 & 0.10 & 3.60 & 0.66 & 1.06 & 0.14 & 0.00 & 0.00 & 0.01 & 14.95 & 555.72 \\
\hline 0.30 & 0.18 & 1.20 & 0.15 & 0.08 & 4.79 & 1.17 & 1.47 & -0.41 & 0.02 & 0.01 & -0.01 & 46.72 & 602.44 \\
\hline 0.25 & 0.15 & 1.10 & 0.14 & 0.07 & 5.75 & 1.69 & 1.94 & -0.47 & 0.02 & 0.02 & -0.01 & 52.72 & 655.16 \\
\hline
\end{tabular}
$1 \%$ dari kedalaman normal.

Tabel 5 Perhitungan Profil Muka air dengan metode Tahapan langsung

Dari hasil interpolasi seperti ditunjukkan pada Tabel 5 diatas, maka pengaruh backwater di sungai Kamoning pada jarak $\pm 537 \mathrm{~m}$ dari hilir adalah setinggi $0,6 \mathrm{~m}$.

\section{Upaya Penanggulangan Genangan Perbaikan Slauran Drainase}

Pada studi ini upaya penanggulangan genangan dengan memperbaiki atau mengubah dimensi saluran drainase yang ada di Kecamatan Sampang berdasarkan evaluasi kapasitas saluran drainase eksisting yang ada. Perubahan dimensi saluran drainase tersebut dilakukan dengan mengubah ketinggian saluran dan lebar saluran seperti yang ditunjukkan pada Tabel 6. 


\section{Perencanaan Kolam Tampungan (kolam Detensi)}

Kolam tampungan direncanakan di beberapa tempat yang dapat menampung debit rencana yang terjadi pada daerah studi seperti ditunjukkan pada Gambar 3.

\section{Volume Kolam Tampungan}

Volume tampungan dihitung berdasarkan luasan yang ada dengan kedalaman 3 meter dari permukaan tanah dengan pertimbangan beda tinggi antara muka air terendah dengan muka air tertinggi adalah 2 meter dari permukaan tanah sedang sisa kedalaman digunakan untuk tampungan sedimen.

a. Perencanaan Kolam Tampungan di desa Pliyang

Kolam tampungan Pliyang direncanakan untuk menampung debit dari outlet PT1 dan TM 1 sebagai berikut :
Luas atas kolam

$$
=27.500,00 \mathrm{~m}^{2}
$$

Tabel 6. Perbaikan Saluran Jaringan Drainase dengan kala Ulang 10Tahun

\begin{tabular}{|c|c|c|c|c|c|c|c|c|c|c|c|c|c|c|}
\hline \multirow{3}{*}{ No } & \multirow{3}{*}{ Nama Saluran } & \multirow{3}{*}{ Lokasi } & \multicolumn{7}{|c|}{ Eksisting Saluran } & \multicolumn{5}{|c|}{ Saluran Rencana } \\
\hline & & & $\begin{array}{c}\text { Luas } \\
\text { Penampang } \\
\text { Basah }\end{array}$ & $\begin{array}{c}\text { Keliling } \\
\text { Basah }\end{array}$ & $\begin{array}{l}\text { Jari-jari } \\
\text { Hidrolis }\end{array}$ & $\begin{array}{c}\text { Koefísien } \\
\text { kekasar } \\
\text { an }\end{array}$ & $\begin{array}{l}\text { Kecepata } \\
\text { n Aliran }\end{array}$ & $\begin{array}{c}\text { Debit } \\
\text { Kapasitas } \\
\text { di Saluran } \\
\text { (Qs) }\end{array}$ & $\begin{array}{c}\text { Debit } \\
\text { Komulatif } \\
\text { Kapasitas } \\
\text { di Saluran } \\
\text { (Qs) }\end{array}$ & $\begin{array}{c}\text { Luas } \\
\text { Daerah } \\
\text { Tangkapan } \\
\text { Air }\end{array}$ & $\begin{array}{l}\text { Limpasan } \\
\text { (C) }\end{array}$ & $\begin{array}{c}\text { Intensitas } \\
\text { Hujan (I) }\end{array}$ & $\begin{array}{c}\text { Debit } \\
\text { Limpasan di } \\
\text { saluran } \\
Q= \\
\text { 0.278.C.I.A }\end{array}$ & $\begin{array}{c}\text { Cek } \\
\text { Kapasitas }\end{array}$ \\
\hline & & & $\mathrm{m}^{2}$ & $\mathbf{m}$ & & & $\mathrm{m} / \mathrm{dtk}$ & $\mathrm{m}^{3} / \mathrm{dtk}$ & $\mathrm{m}^{3} / \mathrm{dtk}$ & $\mathrm{km}^{2}$ & & $\mathrm{~mm} / \mathrm{jam}$ & & Qs > Qd \\
\hline 1 & Sal. Jl. Delima Pasean & P3 & 0.360 & 1.80 & 0.200 & 0.013 & 1.330 & 0.479 & 0.479 & 0.096 & 0.460 & 14.758 & 0.181 & Cukup \\
\hline 2 & Sal. Jl. Raya Panggung & P4 & 0.490 & 2.10 & 0.233 & 0.013 & 2.152 & 1.055 & 1.055 & 0.344 & 0.462 & 14.758 & 0.653 & Cukup \\
\hline 3 & Sal. Jl.H. Abdul Wahab 1 & GM 7 & 0.640 & 2.40 & 0.267 & 0.025 & 1.275 & 0.816 & 0.816 & 0.399 & 0.415 & 14.758 & 0.679 & Cukup \\
\hline 4 & Sal. Jl.H. Abdul Wahab 1 & GM9 9 & 0.520 & 2.10 & 0.248 & 0.025 & 1.164 & 0.605 & 0.605 & 0.301 & 0.415 & 14.758 & 0.512 & Cukup \\
\hline 5 & $\begin{array}{l}\text { Sal. Jl. Karongan } \\
\end{array}$ & TM1 & 0.360 & 1.80 & 0.200 & 0.013 & 2.058 & 0.741 & 0.741 & 0.276 & 0.434 & 14.758 & 0.492 & Cukup \\
\hline 6 & $\begin{array}{l}\text { Sal.JI. Jaksa Agung } \\
\text { Suprapto }\end{array}$ & GS 1'Kiri & 0.250 & 1.50 & 0.167 & 0.013 & 1.068 & 0.267 & 0.267 & 0.103 & 0.455 & 14.758 & 0.193 & Cukup \\
\hline 7 & Sal. Jl. Kusuma Bangsa & GS 2 & 0.756 & 2.43 & 0. & 0. & 0.866 & 0.655 & 0.655 & 0.303 & 0.415 & 14.758 & 0.515 & Cukup \\
\hline 8 & Sal. Jl. Permata Indah & B.12 & 0.393 & 1.80 & 0.218 & 0.013 & 2.080 & 0.817 & 0.817 & 0.104 & 0.532 & 14.758 & 0.227 & Cukup \\
\hline 9 & Sal. Jl. Becik & KD. 1 & 0.490 & 2.10 & 0.233 & 0.013 & 1.210 & 0.593 & 0.593 & 0.273 & 0.442 & 14.758 & 0.494 & Cukup \\
\hline 10 & Sal. Jl. Aengsareh & $\mathrm{AE} 1$ & 0.490 & 2.10 & 0.233 & 0.013 & 1.206 & 0.591 & 0.591 & 0.284 & 0.400 & 14.758 & 0.466 & Cukup \\
\hline 11 & Sal. Jl. Dassan & $\mathrm{AE} 2$ & 0.360 & 1.80 & 0.200 & 0.013 & 1.116 & 0.402 & 0.402 & 0.141 & 0.471 & 14.758 & 0.273 & Cukup \\
\hline 12 & Sal. Jl. Mandangin & $\mathrm{AE} 4$ & 0.360 & 1.80 & 0.200 & 0.013 & 1.234 & 0.444 & 0.444 & 0.163 & 0.446 & 14.758 & 0.298 & Cukup \\
\hline & Sal. Jl. Rajawali & PL 9 & 0.360 & 1.80 & 0.200 & 0.013 & 1.001 & 0.360 & 0.360 & 0.139 & 0.502 & 14.758 & 0.287 & Cukup \\
\hline
\end{tabular}

b. Perencanaan Kolam Tampungan di Jl. Manggis A

Kolam tampungan Jl. Manggis A direncanakan untuk menampung debit dari outlet GS 18 dengan data sebagai berikut :

Luas atas kolam $\quad=3.540,00 \mathrm{~m}^{2}$

Luas bawah kolam $\quad=2.862,00 \mathrm{~m}^{2}$

Volume total $\quad=9.603 \mathrm{~m}^{3}$

Volume tampungan mati $=3.201 \mathrm{~m}^{3}$

Volume tampungan efektif $=6.402 \mathrm{~m}^{3}$

c. Perencanaan Kolam Tampungan di Jl. Manggis B

Kolam tampungan Jl. Manggis B direncanakan untuk menampung debit dari outlet GS 18 dengan data sebagai berikut :

Luas atas kolam $\quad=3.432,00 \mathrm{~m}^{2}$

Luas bawah kolam $\quad=2.736,00 \mathrm{~m}^{2}$

Volume total $\quad=9.252 \mathrm{~m}^{3}$

Volume tampungan mati $=3.084 \mathrm{~m}^{3}$

Volume tampungan efektif $=6.168 \mathrm{~m}^{3}$
Luas bawah kolam $\quad=25.466,00 \mathrm{~m}^{2}$

Volume total $\quad=79.449,00 \mathrm{~m}^{3}$

Volume tampungan mati $=26.483,00 \mathrm{~m}^{3}$

Volume tampungan efektif $=52.966,00 \mathrm{~m}^{3}$

Lokasi kolam tampungan di dusun Pliyang dapat mengurangi genangan yang terjadi di daerah Permata selong dan sekitarnya karena daerah rencana kolam tampungan berada di bagian hulu sehingga diharapkan dapat mengurangi debit yang mengalir ke bagian hilir dengan menampung terlebih dahulu. Berdasarkan informasi masyarakat, rencana lokasi kolam tampungan ini merupakan daerah cekungan yang dahulunya juga selalu terisi air limpasan hujan. Hal ini juga dapat dilihat bahwa dilokasi rencana kolam tampungan banyak ditumbuhi tanaman pandan air. Namun saat ini jarang terisi air karena penuh sedimen sehingga dimanfaatkan masyarakat untuk bercocok tanam. 
Kolam tampungan Paseyan direncanakan untuk menampung debit dari outlet PS.1 dengan data sebagai berikut :
Luas atas kolam
$=9.152,00 \mathrm{~m}^{2}$
Luas bawah kolam
$=8.036,00 \mathrm{~m}^{2}$
Volume total
$=25.782 \mathrm{~m}^{3}$
Volume tampungan mati $=8.594 \mathrm{~m}^{3}$
Volume tampungan efektif $=17.188 \mathrm{~m}^{3}$

Lokasi kolam tampungan di dusun Paseyan dapat mengurangi genangan yang terjadi di daerah Paseyan dan sekitarnya sehingga dapat mengurangi debit yang mengalir ke daerah kelurahan Dalpenang dengan menampung terlebih dahulu. Berdasarkan survey dan informasi masyarakat, rencana lokasi kolam tampungan ini merupakan daerah cekungan yang dahulunya juga selalu terisi air limpasan hujan.

f. Perencanaan Kolam Tampungan di Jl. Imam Bonjol

Kolam tampungan Jl. Imam Bonjol direncanakan untuk menampung debit dari outlet dengan data sebagai berikut :

Luas atas kolam

$$
=29,344,00 \mathrm{~m}^{2}
$$

Luas bawah kolam

$=27.250,00 \mathrm{~m}^{2}$

Volume total

$=84.891 \mathrm{~m}^{3}$

Volume tampungan mati $=28.297 \mathrm{~m}^{3}$

Volume tampungan efektif $=56.594 \mathrm{~m}^{3}$

Lokasi kolam tampungan di Jl. Imam Bonjol dapat mengurangi genangan yang terjadi di daerah Jl. Imam Bonjol, Jl. Suhadak dan sekitarnya sehingga dapat mengurangi debit yang mengalir ke daerah kelurahan Dalpenang dengan menampung terlebih dahulu. Berdasarkan survey dan informasi masyarakat, rencana lokasi kolam tampungan ini merupakan daerah cekungan yang dahulunya juga selalu terisi air limpasan hujan.

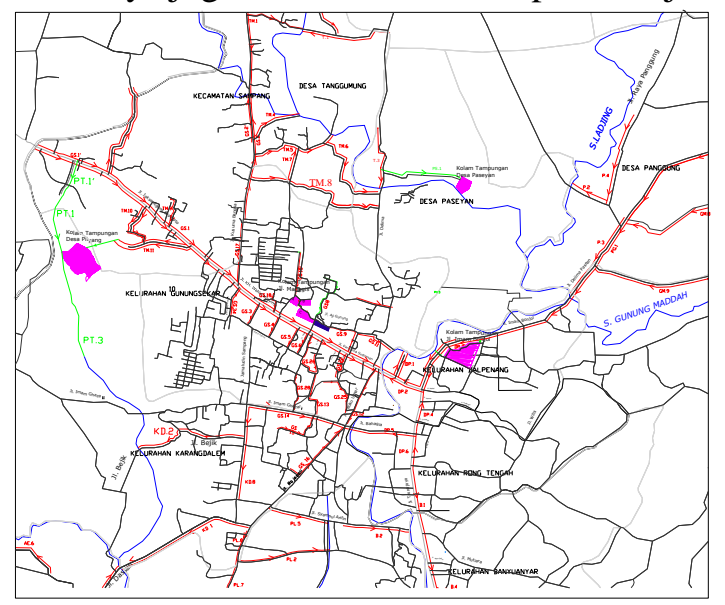

Gambar 3. Peta Lokasi Kolam Tampungan

2. Hidrograf Aliran
Hidrograf aliran pada saluran digunakan untuk merencanakan kapasitas kolam. Hidrograf aliran menggunakan rumus rasional sehingga bentuk umum hidrografnya adalah segitiga, dimana Qp menggunakan harga-harga pada perhitungan banjir rencana. Dengan menggunakan Hidrograf segitiga akan didapatkan volume tampungan pada kolam tampungan.

Berdasarkan perhitungan hidrograf aliran maka di dapatkan komulatif debit aliran kolam tampungan kala ualang 5 tahun adalah
1. Dusun Pliyang $=29.951 \mathrm{~m}^{3}$
2. Jl. Manggis $A=3.680 \mathrm{~m}^{3}$
3. Jl. Manggis B $=3.616 \mathrm{~m}^{3}$
4. Jl. Manggis $\mathrm{C}=4.728 \mathrm{~m}^{3}$
5. Desa Paseyan $=9.672 \mathrm{~m}^{3}$
6. Jl. Imam Bonjol $=36.879 \mathrm{~m}^{3}$

Sedangkan perhitungan hidrograf aliran maka di dapatkan komulatif debit aliran kolam tampungan kala ualang 10 tahun adalah
1. Dusun Pliyang $=35.751 \mathrm{~m}^{3}$
2. Jl. Manggis A $=4.393 \mathrm{~m}^{3}$
3. Jl. Manggis $\mathrm{B}=4.316 \mathrm{~m}^{3}$
4. Jl. Manggis $\mathrm{C}=5.644 \mathrm{~m}^{3}$
5. Desa Paseyan $=11.545 \mathrm{~m}^{3}$
6. Jl. Imam Bonjol $=44.053 \mathrm{~m}^{3}$

\section{Analisis Efektivitas kolam tampungan}

Kemampuan mereduksi genangan yang terjadi sangatlah tergantung pada volume yang masuk dan ruang yang tersedia untuk menampung volume air yang masuk kedalam kolam tampungan. Kemampuan reduksi banjir merupakan kemampuan tampungan dapat menampung kelebihan air banjir.

Tabel 8. Rekapitulasi Reduksi Banjir dengan kolam tampungan

\begin{tabular}{|c|c|c|c|c|c|c|c|}
\hline \multirow{3}{*}{$\begin{array}{l}\text { Nama Lokasi Kolam } \\
\text { Tampungan }\end{array}$} & \multirow{2}{*}{$\begin{array}{l}\text { Volume } \\
\text { tampungan } \\
\text { efektif }\end{array}$} & \multicolumn{4}{|c|}{$\begin{array}{cc} & \text { Efektifitas tampungan } \\
\text { Volume Banjir } \quad \text { terhadap volume banjir } \\
\text { rencana }\end{array}$} & \multicolumn{2}{|c|}{ Reduksi Banjir } \\
\hline & & $\begin{array}{l}\text { Kala Ulang } \\
5 \text { Tahun }\end{array}$ & $\begin{array}{l}\text { Kala Clang } \\
10 \text { Tahun }\end{array}$ & $\begin{array}{l}\text { g Kala Ulan: } \\
5 \text { Tahun }\end{array}$ & $\begin{array}{l}\text { Kala Clang } \\
10 \text { Tahun }\end{array}$ & $\begin{array}{l}\text { Kala Clang } \\
5 \text { Tahun }\end{array}$ & $\begin{array}{l}\text { g Kala Clang } \\
10 \text { Tahun }\end{array}$ \\
\hline & $\mathrm{m}^{3}$ & $\mathrm{~m}^{3}$ & $\mathrm{~m}^{3}$ & $\%$ & $\%$ & $\%$ & $\%$ \\
\hline Desa Pliyang & 52,966 & 29,951 & 35,751 & 177 & 148 & 43.45 & 32.50 \\
\hline JL. Mangis A & 6,402 & 3,680 & 4,393 & 174 & 146 & 42.52 & 31.39 \\
\hline JL Manggis B & 6,168 & 3,616 & 4,316 & 171 & 143 & 41.38 & 30.03 \\
\hline IL Mangis C & 8,370 & 4,728 & 5,644 & 177 & 148 & 43.51 & 32.57 \\
\hline Desa Paseyan & 17,188 & 9,672 & 11,545 & 178 & 149 & 43.73 & 32.83 \\
\hline JL. Imam Bonijol & 56,594 & 36,879 & 4,053 & 153 & 128 & 34.84 & 22.16 \\
\hline
\end{tabular}

Berdasarkan rekapitulasi reduksi banjir pada Tabel 8. ditunjukkan bahwa analisa efektivitas pada 6 kolam tampungan diatas terhadap volume banjir rencana kala ulang 5 tahun rata- 
rata sebesar $172 \%$ dan kala ulang 10 tahun rata-rata sebesar $144 \%$ sehingga tampungan dapat menampung kelebihan air banjir (reduksi banjir) kala ulang 5 tahun rata-rata sebesar $43,57 \%$ dan kala ulang 10 tahun rata-rata sebesar $30,25 \%$.

\section{KESIMPULAN}

Dari hasil pembahasan maka dapat disimpulkan beberapa hal sebagai berikut :

1. Dari hasil analisa pada bab sebelumnya, kapasitas tampungan saluran drainase eksisiting pada saluran drainase Kecamatan Sampang dengan kala ulang 5 tahun dan 10 tahun, beberapa saluran tidak mencukupi sehingga air melimpas dan tergenang. Dari 90 ruas saluran eksisiting drainase Kecamatan Sampang ada 8 ruas saluran drainase yang tidak memenuhi kapasitasnya dengan kala ulang 5 tahun dan 13 ruas saluran drainase dengan kala ulang 10 tahun dengan debit rata-rata $0,46 \mathrm{~m}^{3} / \mathrm{dtk}$. Sedangkan kapasitas Kolam tampungan eksisiting di Jl. Ajigunung sebesar 3,325 $\mathrm{m}^{3}$ dengan tinggi sedimen sebesar $2 \mathrm{~m}$.

2. Pengaruh pasang surut air laut terhadap genangan dari sungai Kamoning pada patok 28 dari hilir menuju menuju hulu saluran B12 sejauh $537 \mathrm{~m}$ adalah $0,6 \mathrm{~m}$.

3. Upaya pengendalian genangan pada daerah studi yaitu :

a. Perlu dilakukan perbaikan saluran dengan meningkatkan kapasitas saluran eksisiting.

b. Perlu dilakukannya pengerukan pada kolam tampungan eksisiting yang tinggi sedimen sudah mencapai 2 meter dengan volume tampungan sebesar $6.650 \mathrm{~m}^{3}$.

c. Analisis efektivitas kolam tampungan pada 6 lokasi di kecamatan didapatkan rata-rata sebesar $172 \%$ dengan kala ulang 5 tahun dan $144 \%$ dengan kala ulang 10 tahun. Sedangkan kemampuan reduksi banjir yang terjadi pada 6 lokasi dikecamatan di dapatkan rata-rata sebesar 43,57\% kala ulang 5 tahun dan $30,25 \%$ kala ulang 10 tahun.

\section{UCAPAN TERIMA KASIH}

Terima kasih kepada Badan Pengembangan Sumber Daya Manusia (BPSDM) Kementrian Pekerjaan Umum dan Perumahan Rakyat, Pusat Pendidikan dan Pelatihan (PUSDIKLAT) Bandung yang telah mendanai penelitian ini, dan Pemerintah Kabupaten Sampang serta semua pihak atas dukungan dan partisipasinya selama penelitian ini.

\section{DAFTAR PUSTAKA}

Hapsari, R.H. (2014). Kajian Efektivitas Kolam Detensi Kuningan UGM Untuk Pengurangan Banjir Kali Belik. Universitas Gajah Mada Semarang.

BMKG. (2016a). Laporan Curah Hujan. Surabaya: Tidak dipublikasikan.

BMKG. (2016b). Laporan Pasang Surut Air Laut. Surabaya: Tidak dipublikasikan.

BPS Sampang, K. S. (2015a). Kabupaten Sampang Dalam Angka. Sampang: Tidak dipublikasikan.

BPS Sampang, K. S. (2015b). Kecamatan Sampang dalam Angka. Sampang: Tidak dipublikasikan. 
